\title{
Immigration metaphors in a corpus of legal English: an exploratory study of EAL learners' metaphorical production and awareness
}

\author{
Metáforas sobre inmigración en un corpus de inglés jurídico: \\ un estudio preliminar de la producción y conciencia metafórica \\ de estudiantes de inglés como lengua adicional (EAL)
}

\author{
Emilia Castaño ${ }^{\mathrm{a}}$ Castaño, Natalia Judith Laso Martín ${ }^{\mathrm{b}}$ \\ $\&$ Isabel Verdaguer Clavera ${ }^{c}$
}

\author{
a University of Barcelona. e.castano@ub \\ b University of Barcelona. njlaso@ub.edu \\ c University of Barcelona. i.verdaguer@ub.edu \\ Received: 20/04/2017. Accepted: 31/10/2017
}

\begin{abstract}
Metaphor is central to human understanding and communication. It pervades our everyday language and also abounds in specialized discourse, with legal language not being an exception. This is particularly relevant since metaphors are powerful framing tools able to affect our worldview. With the aim of exploring the use that EAL law undergraduate students make of metaphorical expressions as well as their awareness of their connotations, a learner corpus was compiled and qualitatively analyzed. Results have shown that learners, like native speakers, rely on the use of conceptual metaphors such as MIGRATION IS A NATURAL FORCE, STATES ARE CONTAINERS or IMMIGRANTS ARE A THREAT to describe immigration issues. This exploratory study has also revealed that learners are not always conscious of the negative slant that metaphors may convey and that raising their awareness is key to enhance critical thinking.
\end{abstract}

Keywords: corpus linguistics; conceptual metaphor; metaphorical awareness; legal discourse; EAL learners.

Resumen: La metáfora es un elemento central de la comunicación y la comprensión humana. Abunda en el lenguaje cotidiano y también en el de especialización, no siendo una excepción el discurso legal. Este hecho es relevante ya que las metáforas nos permiten enmarcar la realidad desde diversas perspectivas que condicionan nuestra per-

\ Castaño Castaño, Emilia; Laso Martín, Natalia Judith \& Verdaguer Clavera, Isabel. 2017. "Immigration metaphors in a corpus of legal English: an exploratory study of EAL learners' metaphorical production and awareness". Quaderns de Filologia: Estudis Lingüistics 22: 245-272. doi: 10.7203/qf.22.11310 
cepción del mundo. Con el objetivo de explorar el uso que los estudiantes de Derecho con inglés como lengua adicional (EAL) hacen de las metáforas y de determinar si son conscientes de sus connotaciones, se compiló y analizó cualitativamente un corpus de aprendices. Los resultados han demostrado que los aprendices al igual que los hablantes nativos utilizan metáforas conceptuales tales como LA INMIGRACIÓN ES UNA FUERZA NATURAL, LOS ESTADOS SON CONTENEDORES O LOS INMIGRANTES SON UNA AMENAZA para describir el fenómeno de la inmigración. Este estudio exploratorio también subrayó la importancia de que los aprendices sean conscientes de la carga negativa de algunas metáforas para promover el pensamiento crítico.

Palabras clave: metáfora conceptual; conciencia metafórica; discurso legal; aprendices de EAL; lingüística de corpus. 


\section{Corpus linguistics and metaphor}

Word meanings are multi-faceted and can present multiple sides, which vary depending on the perspective from which they are viewed. Words in isolation are ambiguous but their ambiguity is lost or reduced when they are put in context. They have meaning potential, which is activated in a given context (Hanks, 2007). Many words, in addition to their literal meanings, have metaphorical meanings, which often reflect the cognitive operations whereby we understand complex concepts (Lakoff \& Johnson, 1980, 1999). Thus, the meaning of rise in (1) is concrete and refers to motion and in (2) it is metaphorical and refers to quantity.

(1) By the time the plane rose in to the air it was dark (British National Corpus)

(2) Aluminium recycling in the UK rose to 9.5 last year (British $\mathrm{Na}$ tional Corpus)

Corpus linguistics, which has allowed to analyze real language in context, first approached the analysis of the syntagmatic patterns of language. More recently, however, it has also been applied to the analysis of figurative language, offering a way to carry out quantitative and qualitative studies of metaphorical expressions as a phenomenon of language in use. The availability of electronic corpora has enabled the systematic search for metaphorical expressions in authentic texts and has provided empirical evidence for the theoretical claims of the theory of Conceptual Metaphor (Cameron \& Deignan, 2003; Stefanowitsch, 2007).

The identification and analysis of metaphorical expressions is methodologically much more complex than the study of lexical items, for example, since metaphorical mappings have different lexical realizations and cannot be extracted from texts in a straightforward way. For this reason, a number of procedures for metaphor extraction have been devised, among them, manual searching; search for source-domain vocabulary; search for target-domain vocabulary; search for both source and target-domain, or search based on 'markers of metaphor' realizations, that is to say, linguistic devices that may indicate the presence of a metaphor (see Stefanowitsch, 2007 for an account of the problems encountered in automatic metaphor extraction). 
In addition, literature has shown that figurative language is used not only in general language, but also in different types of genres and registers (Deignan et al., 2013). Recent research (Caballero, 2003, 2006; Deignan et al., 2013; Herrmann \& Sardinha, 2015) has stressed the need to take into account register and the specific linguistic characteristics of a discourse community in the exploration of figurative language, due to the relevance of shared knowledge in the production, recognition and interpretation of metaphors. Finally, corpus linguistics has also greatly contributed to aiding critical metaphor analysis by providing attested linguistic evidence of the framing-evaluative power of metaphor (Charteris-Black, 2005).

\section{Metaphor and Framing}

The advent of Cognitive Metaphor Theory in the early 1980s shifted the locus of metaphor from language to thought and posited the claim that abstract concepts are metaphorically grounded in experiences arising from our embodied interactions with the environment, which "[is] at once physical, social, cultural, economic, moral, legal, gendered, and racialized" (Johnson, 2007). In this respect, metaphor, far from being considered an ornamental device, is conceived of as a cognitive operation whereby abstract domains (target domains) are mapped onto concrete experiential domains (source domains) through projections that under the form 'TARGET DOMAIN IS SOURCE DOMAIN' allow us to understand, reason, and talk about abstract concepts and subjective or complex experiences in terms of more concrete ones (Lakoff \& Johnson, 1980, 1999; Semino, 2008). This property of metaphor makes it a powerful framing tool, able to shape the way we perceive a situation or event by evoking particular worldviews and highlighting certain aspects of a phenomenon while downplaying others (Lakoff \& Johnson, 1980, 1999; Lakoff, 2004; Charteris-Black, 2005; Johnson, 2007). Thus, for example, the choice of metaphors related to either sports or war to describe a country's foreign policy frames the topic in different and contrasting ways: while sports metaphors depict foreign countries as opponents, war metaphors do it as enemies, foregrounding the notion of hostility. This property of metaphor transcends language boundaries, by helping "to promote a particular problem definition, causal interpretation, moral evaluation and/or treatment recommendation for the item 
described" (Entman, 1993: 52). Hence, metaphor becomes an exceptional instrument to analyze the conventional understanding of some of the most controversial topics included in the journalistic, political and legal agenda, such as, for example, immigration.

\section{Immigration Metaphors in Public Discourse}

A large body of studies has lately analyzed the metaphorical expressions that have shaped the European and American discourse on immigration in our recent history, as reflected by mass media, blogs and political speeches (O’Brien, 2003; Charteris-Black, 2006; Wodak, 2006; Cisneros, 2008; Biria, 2012; Musolff, 2015; Saiz de Lobado, 2015; among others). From their results it becomes apparent that, despite cross-cultural variation, the portrayal of immigration that has dominated public discourse since the early 20th century, at one point or another, has revolved around a network of metaphors that dehumanize immigrants and/or describe them as a threat to host countries. Thus, for example, several studies have shown that immigration is often described as A NATURAL FORCE, A FLOOD, with an uncontrollable power and disastrous consequences for recipient communities (Santa Ana, 2002; O'Brien 2003; Charteris-Black, 2006; Chavez \& Hoewe, 2012; Strom \& Alcock, 2017). Similar devastating effects have been found to be attributed to immigration in metaphors that equate immigrants with MOBILE TOXIC WASTES (Cisneros, 2008) or WEEDS that infest the land (Deignan, 2005).

Research has also provided evidence that subhuman metaphors such as IMMIGRANTS ARE ANIMALS (Santa Ana, 1999; Deignan, 2005), OBJECTS or COMMODITIES (El Refaie, 2001; O'Brien 2003) have coexisted, at least since the 1990's, with metaphors that bestowed nations with human qualities and led to conceptualize them as a BODY OR ORGANISM whose wellbeing is endangered by immigrants, seen now as either a BURDEN (Santa Ana, 2002; Cisneros, 2008; Crespo-Fernández, 2013), INDIGESTIBLE FOOD, INFECTIOUS ORGANISMS, (O'Brien 2003) or PARASITES (Musolff, 2015). These metaphors seem to have been partially displaced now by those that depict immigrants as INVADERS, CRIMINALS OR ILLEGAL ALIENS (Flores, 2003; Binotto, 2015) against whom a heroic fighter, the government, must act to protect the country's integrity (Santa Anna, 2002; O’Brien 2003; Musolff, 2011; Binotto, 
2015). These metaphors rest on the conceptualization of the NATION AS A HOUSE or FORTRESS (Charteris-Black, 2006; Cisneros, 2008; Biria, 2012) whose boundaries, either physical or symbolic, serve the purpose of setting a dividing line between the $u s$ and them (Van Dijk, 2000) and reinforce the sense of otherness that seems to pervade not only public, as seen in this section, but also legal discourse on immigration, as will be discussed in the following section.

\section{Immigration metaphors in legal discourse}

In spite of the preconceived idea that specialized registers are largely free from figurative expressions, expanding research gives proof that metaphor is widely used in specific text-types (Deignan et al., 2013): in the fields of politics and economics (Musolff, 2004; Charteris-Black, 2005); in medicine (Salager-Meyer, 1990; Faber \& Márquez, 2004); in biology (Ureña, 2012; Knudsen, 2015) are just a few examples. In this respect, legal discourse is not an exception. Legal discourse is highly metaphorical to the extent that conceptual metaphor and radial categories are argued to shape legal language and, to a certain extent, determine which arguments are valid in legal reasoning (Winter, 2001, 2006; Ebbesson, 2008). This results logical if it is considered that law is "an ideological artifact" (Orts, 2015: 30), a product of human understanding, which is essentially metaphorical (Lakoff \& Johnson, 1999; Johnson, 2007). Metaphors act as framing instruments not only able to convey legal concepts but also to influence thought and policies. Beyond theoretical assertions, the ubiquity of metaphor in law has been extensively attested both in general (Winter, 2006) and specific legal domains such as corporate and criminal law (Duncan, 1994; Berger, 2004); constitutional and administrative law (Noah, 2000; Jackson, 2006); or intellectual property regulation (Loughlan, 2006; Larsson, 2013). In the case of immigration law, several studies have shown that metaphor also plays an important role in the legal construct of immigration. Thus, for instance, according to Cunningham-Parmeter (2011), the analysis of the American Supreme Court texts evidences that for decades immigration has been commonly conceptualized as A FLOOD, AN AVALANCHE or AN INVASION, and immigrants, as ALIEN OUTSIDERS or ILLEGALS that threaten the country's stability. These same images repeat in the European legislation where immigration is also depicted as AN UNCONTROL- 
LABLE FLUID and the NATION AS A CONTAINER metaphor grounds the proliferation of exclusion metaphors such as IMMIGRANTS ARE ALIENS or ENEMIES to be fought (Rosello, 1999; Incelli, 2013). In this context, border protection is given priority, which leads to adopt a CLOSEDDOOR POLICY towards immigrants. Only occasionally, the metaphor of hospitality, closely connected to the former, is invoked and immigrants are presented as GUESTS who enjoy the generosity of a HOST whose borders are now seen as AN OPEN DOOR (Rosello, 1999). Finally, the legal system also seems to draw on the metaphor IMMIGRANTS ARE OBJECTS (Incelli, 2013), in which immigrants are conceived of as entities that can be relocated.

A close reading of the dominant metaphorical construction of immigration described above reflects a tight connection with what Lakoff called the strict father model (Lakoff, 1996, 2006; Lakoff \& Wehling, 2012). Framing immigration as a security problem and immigrants as illegal aliens or invaders (Lakoff \& Ferguson, 2006) appeals to the governments' duty of protecting their citizens, just as a father would do, and contributes to enhancing the treatment of immigration as a threat in public and legal discourse.

\section{The conceptualization of immigration in a learner corpus of legal English}

Metaphors are a fundamental part of linguistic competence and need to be addressed in second and foreign language learning and teaching. Early research in this area (Boers, 2000; Littlemore \& Low, 2006) has mostly focused on the importance of raising learners' awareness of metaphorical thought during the language learning process. In particular, it has approached the students' learning and understanding of metaphors as well as the metaphorical extension of the meaning of words to facilitate vocabulary learning, since it has been demonstrated that making learners aware of the relationship between the literal and figurative meanings of lexical items (Boers, 2000; Charteris-Black, 2000) aids the comprehension and retention of new vocabulary.

Learners, however, in addition to being familiar with conceptual metaphor and the metaphorical extension of meaning of certain expressions, need to learn and use the linguistic instantiations of metaphorical thought in the target language (Charteris-Black, 2000). As Boers (2000) 
points out, knowledge of metaphorical thought does not guarantee the command of its linguistic realizations. Thus, metaphoric competence, that is, the ability to recognize and use figurative language effectively and appropriately, is indeed a relevant step in the language learning process.

Yet, to this date there are still few studies approaching the students' actual production of metaphorical expressions in L2. In spite of the great expansion that research on learner corpora has seen in the last decade, after Granger's pioneering work and the compilation of the International Corpus of Learner English (ICLE) (Granger et al. 2002), followed by the compilation of many other learner corpora, little research has been published on the actual use of metaphor by learners (Littlemore \& Low, 2006; Chapetón et al., 2012; Golden, 2012; Nacey, 2013; Littlemore et al., 2014). As shown earlier, there are several studies dealing with the study of metaphor in both public discourse and legal discourse. A few have also approached metaphors in the language of learners or non-experts, and, very recently, the metaphors used by migrant students in their account of their own experiences (Catalano, 2016). However, to our knowledge, no study has analyzed the use of immigration metaphors in a learner corpus of legal English.

This paper, which approaches the metaphorical conceptualization of immigration in an EAL ${ }^{1}$ learner corpus of legal English, aims to fill a gap in learner corpus research. Its objective is to analyze the use of figurative language in a corpus of texts on migration law written in English by Spanish undergraduates of Law and test their awareness of the evaluative power of metaphor. Although there are a few corpus-based studies on the use of metaphors by learners (mentioned above) claiming that learners do use metaphorical expressions, they focus on students' general argumentative writing, not on a specialized register. To our knowledge, there is no other learner corpus of legal English which has been compiled and analyzed so far.

Being immigration a highly debated and controversial topic, and an important social issue in western society, metaphorical language is expected to play a major role in learners' production. If so, can university students of law recognize the metaphors used in legal discourse as well

\footnotetext{
${ }^{1}$ The term EAL was preferred to EFL/ESL here as the population under study has been instructed in English.
} 
as their connotations? And do they reproduce metaphors charged with negative associations without, perhaps, even being aware of them?

\section{Data and Method}

\subsection{Learner corpus data and learner profile used in this study}

With the aim of exploring the use that learners make of metaphors in their legal English written production and what type of conceptualizations are being used, twenty-five unrevised written assignments (circa 25,000 tokens) on European immigration and asylum produced by thirty Spanish undergraduate students of Law who use English as an Additional Language (EAL) were selected. Admittedly, this is a small corpus, which will be enlarged in the future, but taking into account that some previous studies on metaphor in learner corpora are based on small datasets (Nacey, 2013), we think ours is enough as an exploratory qualitative study which can provide valid conclusions about the use of figurative language and the patterns followed in this type of discourse. This collection of texts has been constructed to inform the VESPA ("Varieties of English for Specific Purposes dAtabase") learner corpus project, aimed at building up a large corpus of ESP texts written by L2 writers from various mother tongue backgrounds.

This group of undergraduates was enrolled in a 6 ECTS optional course on Migration Law and Citizenship, which examines the rules and policies developed by the European Union and Member States in order to manage migration flows. In addition to describing this phenomenon both at the EU and at national level, the course also focuses on EU and national powers that govern the entrance, removal and status of non-nationals. The difference between Union citizens and third-country nationals is also analysed and compared, as well as the status of family members of Union citizens. The acquisition of citizenship by former migrants and the special situation of asylum seekers are also addressed.

Regarding the learning outcomes of the course, learners are expected, on the one hand, to gain knowledge on the basic concepts of migration law, asylum and citizenship as well as the rules that govern migration both at EU and national level and, on the other, acquire a better command of migration terminology and associated phraseology in English. 
No level of language proficiency is required to enrol in the course, but learners sit a placement test during the first week of the course and their English proficiency level ranges from B1 to C2, using the CEFR system.

\subsection{Survey}

In order to attest learners' awareness of the use of metaphorical expressions usually associated with the role and functions of the government and laws, as far as immigration policies are concerned, a survey was handed out among participants to the study (see Appendix). In this study, we present qualitative results on part 3, in which respondents were given some information about metaphors as mechanisms used to understand one concept in terms of another and were asked whether they were aware of the fact that legal discourse was highly metaphorical and that certain terms were associated with negative connotations. They also had to justify their answers.

\subsection{Metaphor extraction}

Following the "metaphor identification procedure" (MIP; Pragglejaz Group 2007; Steen et al., 2010), a 25,000-word sample from a learner corpus of legal English was analysed manually in order to identify the most salient metaphorically used expressions; that is, expressions that have a contextual (metaphorical) meaning that can be understood in comparison with a more basic (literal) meaning, commonly found in the learners' essays. Each of these expressions was classified according to their source domain.

With the aim of ensuring accuracy and consistency, three analysts were involved in the metaphor identification process. The analysts are all linguists and researchers specialised in discourse analysis. Their individual results were discussed and only those metaphorical expressions agreed among the three analysts were selected for the present study. Finally, these expressions were compared against those already identified in native production (O'Brien, 2003; Charteris-Black, 2006; among others). 


\section{Results and Discussion}

\subsection{Metaphor analysis}

Corpus data reveal that learners use a large number of metaphorical expressions and that the most frequent conceptual metaphors used by learners in our corpus of legal English to depict immigration and its actors can be grouped as follows: NATIONS ARE CONTAINERS, IMMIGRATION IS A THREAT/PROBLEM; IMMIGRATION CONTROL IS A BATTLE, IMMIGRATION IS A NATURAL FORCE; IMMIGRANTS ARE OBJECTS.

\subsubsection{NATIONS ARE CONTAINERS}

The analysis of the examples found in the learner corpus dataset has shown that learners also conceptualize nations as bounded spaces of limited capacity (Example (3)) vulnerable to collapse in the event of a large-scale increase in immigration (Example (4)) (Rosello, 1999). In this context, governments and institutions become guarantors of protection and border security turns out to be essential for the stability of the country (Example (5)) (Castan Pinos, 2008). Hence, borders are metaphorically conceived of as gates or doors that can be sealed (Example (6)) or selectively opened to people based on criteria of desirability and need (Example (7)) (Zaiotti, 2007).

(3) Relocation as a concept which emphasizes distribution of persons in clear need of international protection among Member States, will be used when the volume of arrivals is already full (ML 19).

(4) With 600.000 people applying for asylum in 2014, the European Union is under a lot of pressure, the system is overwhelmed. These distribution criteria reflect the capacity of the Member States to absorb and integrate refugees (ML 20).

(5) What European institutions have tried to do so far is find a balance between these two apparently opposing obligations: the humanitarian one of saving those in peril and the one of protecting Europe (ML 19).

(6) One of the main arguments of those who believe we should "close our borders" is the fact that we simply do not know if everyone coming in is an actual asylum seeker, or a member of a terrorist group who is just taking advantage of the situation and making his way to Europe (ML 21). 
(7) The EEUU or the UK's primes ministers openly said that they would open the borders for those highly-educated professionals (with no less than a College degree) to seek for opportunities in their countries (ML 22).

The container metaphor implies both an inside and an outside and therefore in relation to immigration discourse it requires both the 'us' and the 'them' referred to by Van Dijk (2000): "the penetration of the boundary of a container implies the 'them' symbolically entering the "us"" (Charteris-Black, 2006: 577). In this sense, borders simultaneously serve the purpose of setting categorization lines that help to distinguish citizens from non-citizens, often referred to as applicants (Examples (8), (9)) to whom states can offer temporary or permanent protection. The metaphor of hospitality is invoked in this case and nations are presented as hosts (Example (10), (11)).

(8) Agenda did not provide Member States with instructions how to do this seperation between applicants if they are facing higher number of applications than expected (ML 19).

(9) Member States shall prevent secondary movements of relocated applicants during the period of the examination of application for international protection (ML08).

(10) Very commendable is that Europol and Eurojust are ready to assist the host Member State with investigations to dismantle the smuggling and trafficking networks (ML 19)

(11) It is important to make progress when it comes to relocation and resettlement with respect to the Member States and third countries which host large numbers of refugees (ML21).

All in all, the examples above provide a picture of immigration that frames it as a problem mainly related to having to cope with more than a fair share of refugees and migrants, which has justified the adoption of a protection policy oriented to controlling the porosity of Europe's borders establishing tight selective criteria.

\subsubsection{IMMIGRATION IS A THREAT/PROBLEM}

As shown in the literature, the social phenomenon of immigration is often portrayed as dangerous in immigration discourse (Santa Ana, 2002; 
Charteris-Black, 2006; Cisneros, 2008, to name but a few). Cisneros (2008: 569) points out that "[t]hough the degree of popular obsession with immigrants rises and falls, there is always an awareness that these strangers potentially bring with them monumental and threatening changes". In this scenario, immigrants are seen as threatening enemies (invaders, troublemakers) and as a danger to the stability of member states.

(12) They are considered to be a threat to public policy, internal security, public health and international relations (ML03)

(13) (...) to check (...) the identity of any person, irrespective of his behaviour and of specific circumstances giving rise to a risk of breach of public order (ML03)

(14) A Member State can apply for temporary protection in the event of a mass influx of displaced persons from third countries who are unable to return to their country of origin and to promote a balance of effort between Member States in receiving and bearing the consequences of receiving such persons (ML05)

(15) EU states tend to view any large-scale international migration as a threat to the sovereignity of their national and regional borders, their economies and their societies (ML21)

As illustrated in the examples above, many expressions of negative evaluation, such as "a threat to public policy, internal security" (Example 12); "a risk of breach of public order" (Example 13); "bearing the consequences of" (Example 14) and "a threat to the sovereignity of their national and regional borders" (Example 15) can be found in the corpus data, which goes in line with those expressions identified in native production.

\subsubsection{IMMIGRATION IS A NATURAL FORCE}

Immigration is conceptualized as a flow of water, as a tidal wave (SOURCE DOMAIN) which is difficult to control and thus is portrayed as a social catastrophe: " (...) by their nature, liquids -tides, rivers, waves, etc. - move around; they can therefore be related to a more primary conceptual metaphor: CHANGES ARE MOVEMENTS" (Kövecses, 2002: 134). To this respect, Charteris-Black (2006: 572) highlights that "lack of control over change is lack of control over movement", which rein- 
forces the idea that the use of disaster metaphors to describe migratory flows implies that the phenomenon of immigration is perceived as a danger (IMMIGRATION IS A THREAT). In addition, within this frame, immigrants are not seen as individuals anymore. On the contrary, they are depicted as an undifferentiated, anonymous and hence dehumanized mass: "understanding migrants as molecules in a liquid depersonalizes and dehumanizes them." (Dervinyte, 2009: 53).

(16) In the event of a mass influx of displaced persons. (ML10)

(17) It means that this situation of a mass influx or imminent mass influx of displaced people from third countries has to be recognised internationally (ML13)

(18) It's just a large migratory flow (ML11)

(19) The complexity of the migrant inflow has put enormous strain on the asylum system. Some countries (...) have reached breaking point in their ability to manage the unplanned inflow and meet EU standards for receiving and processing applicants (ML22)

Expressions such as a "mass influx" (Examples (16) and (17)), "a flow" (Example (18) and "inflow" (Example 19) relate to the image of water. It is also worth noting that as immigration is here represented in terms of a natural force (e.g., flow, influx), it is often described by means of gradable adjectives, such as large or big (Example (18)).

\subsubsection{IMMIGRANTS ARE OBJECTS}

Immigrants are often presented as impersonal or interchangeable objects; that is, materials depicted as cheap labour that can be easily replaced ore removed from one place to another. As pointed out in the literature (O'Brien, 2003; Charteris-Black, 2006), images of immigrants as quantifiable goods (Examples (20) and (21)) discourage empathy with incomers, who are associated with a feeling of fear of destruction:

(20) The controversial issue is the proposal to introduce fixed amounts distribution of refugees among Member States tabled by Germany and rejected by the countries of Central Europe (ML21)

(21) Some countries are now challenging the EU proposals by introducing the number of asylum seekers they are willing to take (ML22) 
The IMMIGRANTS ARE OBJECTS metaphor tends to appear in combination with the NATIONS ARE CONTAINERS metaphor. States are viewed as containers and immigrants are perceived of as dehumanized entities that can be easily relocated from one place to another (Example (22) and (23)) and even exploited as cheap labour (Example 24), which turns them into a SOURCE OF PROFIT (Examples (24) and (25)) that exert pressure on cheap labour (immigrants) that is seen as a threat:

(22) The member state of relocation shall take back the person as they are a threat to the country (ML19)

(23) Some countries are now challenging the EU proposals by introducing the number of asylum seekers they are willing to take (ML22)

(24) Supporting effective management of labour migration to tackle exploitation and support migrant workers (ML23)

(25) Migrants in an irregular situation are also more vulnerable to labour and other forms of exploitation (ML24)

\subsubsection{IMMIGRATION CONTROL IS A BATTLE}

Metaphors that refer to IMMIGRATION IS A BATTLE are also very frequently found in immigration discourse. Immigrants are often portrayed as the invading enemy threatening the stability of the state and, thus, dealing with them requires military action (Biria, 2012: 37):

(26) Europe is facing the biggest wave of refugees after decades. In this moment there is no possibility for Member States to combat illegal pathways of reaching Europe alone (ML22)

(27) To fight the migration massive influx, the EU is trying to solve the problem from the bottom looking for the main reasons that made people move from one country to another (ML20)

In the examples above, the EU is conceptualized as a container which must be protected and kept secure from external dangers, such as, "the biggest wave of refugees" and/or "the migration massive influx". Yet again, immigration is understood in terms of a threat that hinders the stability and integrity of the nation.

The data provided above evidence that metaphors are an inextricable part of learners' description and analysis of migration law, which arises the question whether the construct of immigration that their es- 
says reflect was purposely built upon metaphors or not. As Lakoff \& Turner (1989) point out: "Metaphor is a tool so ordinary that we use it unconsciously and automatically, with so little effort that we hardly notice it" (p. xi). Thus, we are not always necessarily conscious of the metaphors that we use and the connotations that they evoke. To attest learners' metaphorical awareness and assess how conscious they were of the evaluative slant that most of the metaphors used in their written production convey, participants were asked to take a survey that overtly asked about these two aspects.

\subsection{Survey}

After a brief introduction that reported on the pervasiveness of metaphor in language, and the fact that metaphor can influence our perception of the world and our attitudes to it (see Appendix for the complete survey), students were asked to answer two questions:

- Q1. Were you aware that legal language was highly metaphorical?

- Q2. Had you ever realized that the use of terms such as those mentioned above evoke negative connotations? Explain briefly.

Almost $40 \%$ of law students had not realized before that metaphorical expressions are pervasive in this register. This high percentage confirms that it is important to train students to become aware of the use of metaphorical expressions and the associations they have. The first step is thus to raise students' awareness of figurative language; since only if they can recognize the metaphorical use of a specific word, will they be able to understand the associations it may carry.

Then students were asked if they had ever realized that the use of the terms included in the survey evoked negative connotations and had to explain why. It is in the open comments where we can more clearly see the participants' awareness of metaphors and their connotations, since they show different degrees in the students' perception both of metaphors and of their associations. Learners' responses indicate that $72 \%$ of the students who said were conscious of metaphorical language also showed their perception of the negative connotations of the metaphors associated with migration. As the following student's 
comment conveys, words may not be neutral and can carry different connotations:

(28) Yes because the language that you use is not neutral and depending on how you use the words you can transmit different messages. (ML12).

The pejorative connotations of a word in its literal usage are transferred to its metaphorical use which thus also carries a negative message, as shown in the following comment:

(29) Flood in everyday's language is rather a negative word, so connecting "flood" with immigration would always evoke negative connotations. (ML05).

The purpose of these metaphors to communicate a particular view of immigration to justify some governments' policies is also recognized by some of the students:

(30) Yes, the use of this kind of expressions may contain discriminatory clauses, such as even racist connotations; indirectly. Then, it justifies some policies to restrict immigrants rights, as it's happening in a great part of Europe. The law is written by people, so it's obvious it may contain metaphors and political matter. (ML13).

The remaining answers (28\%) were more ambiguous as far as negative connotations are concerned. As connotative meaning is subjective, not all students recognize pejorative implications:

(31) For me words such as flows, influx and curbs don't necessarily have a negative connotation. Matter fact all those words have different uses, and even as metaphors I don't think you can get a universal definition because they have different meanings. (ML02).

(32) Probably because the use of legal terms in a metaphorical way seems easier to understand for laymen from a shallow perspective. While in fact these terms have a very profound and unforseeable load of specific meaning behind them. That's why every word in a legal context is important. (ML06). 
However, most students who were previously unaware of the presence of metaphorical language in legal English realized the negative associations implied in these expressions:

(33) I had never realized before that metaphorical uses of words such as the ones indicated above evoke negative connotations. However, it is obvious once I have seen in that example that they totally evoke negative connotations by subliminally (?) impressing people's subconscious with negative meaning which leads then to think of that phenomenon as something dangerous or harmful. (ML01)

(34) No, I've never realized it, but I think metaphors are useful in this sense because they can bring up different reactions. (ML04).

As reflected in the comments above, making learners conscious of the fact that legal language is highly metaphorical in nature contributes to raising their awareness of the "strategic dimension" (Damele, 2016: 175) that metaphorical expressions play in influencing people's views. The use of metaphors can be unconscious and automatic, thus raising learners' metaphorical awareness is crucial not only to aid language learners' communicative competence and proficiency but also to enhance critical thinking. Arguments in favor of integrating metaphor competence (i.e. the ability to acquire, produce and interpret metaphor (Littlemore \& Low, 2006)) in the second, foreign and specific purposes language curricula have multiplied in the last 30 years (Danesi, 1993, 2008; Littlemore \& Low, 2006; Boers, 2013). This seems logical if we consider that the development of metaphor competence also contributes to improving textual, grammatical, illocutionary, strategic and sociolinguistic competence (Littlemore \& Low, 2006). Thus, for example, explicit metaphor instruction has proven to enhance the expansion and retention of vocabulary (Boers, 2004); the understanding and recalling of polysemous senses and idioms (Kövecses, 2001) or the reduction of negative transfer errors derived from cross-cultural differences in metaphor usage and wording (Boers, 2003, 2004; Campos-Pardillos, 2016). In the case of legal ESP and law studies, an explicit approach to conceptual metaphors and their lexicogrammatical instantiations may help learners not only to detect differences in the metaphorical models that every legal system select to deal with issues such as immigration but 
also to develop the necessary pragmatic skills to uncover the inference patterns and evaluative slant that they evoke.

\section{Conclusion}

Our results have shown that the metaphorical construct of immigration in learners' legal discourse builds upon a web of interrelated metaphors (Ponterotto, 2000; Semino, 2008) that seem to have the metaphor NATIONS ARE CONTAINERS as their core constituent. The fact that countries are conceptualized as bounded areas vulnerable to the irregular entry of third nationals renders immigration as a risk for their internal welfare, which licenses the use of the metaphors IMMIGRATION IS A THREAT and IMMIGRATION CONTROL IS A BATTLE to protect the country's interests. The threat that immigration is thought to pose is often described as a natural hazard, a NATURAL FORCE with catastrophic consequences for the recipient countries. This metaphor contributes to dehumanizing immigrants by equating them with overwhelming flows of water, just as it does their depiction as OBJECTS whose relocation or expulsion represents a relief for the recipient countries. Only when the perspective shifts away from the devastating effects of immigration on nations and focuses instead on immigrants, the figure of nations as protective HOSTS emerges. Our analysis has also evidenced that public, legal and learners' discourse on immigration are largely shaped by a common metaphorical model, which is so highly entrenched that its use and negative slant often go unnoticed by learners. Finally, this study has also proved that bringing to the fore the connotations and power relationships implicit in a given choice of words positively helps learners to take a critical stance towards seemingly neutral terms and realize that words always matter.

\section{Acknowledgements}

We acknowledge the support of the Agència de Gestió d'Ajuts Universitaris $i$ de Recerca (2014 SGR 1374) and the beca de formación en ivestigación y docencia de la Fundación Obra Social y Universidad de Barcelona (grand held by Emilia Castaño). The authors are also grateful to two anonymous reviewers for their comments. 


\section{References}

Berger Linda, L. 2004. What is the sound of a corporation speaking? How the cognitive theory of metaphor can help lawyers shape the law. Journal of the Association of Legal Writing Directors 2: 169-208.

Binotto, Marco. 2015. Invaders, Aliens and Criminals: Metaphors and Spacesin the Media Definition of Migration and Security Policies. In Bond, Emma; Guido, Bonsaver \& Faloppa, Federico (ed.) Destination Italy: Representing Migration in Contemporary Media and Narrative. Oxford: Peter Lang, 31-58.

Biria, Ensieh. 2012. Figurative Language in the Immigration Debate: Comparing Early 20th Century and Current U.S. Debate with the Contemporary European Debate. (Thesis). http://pdxscholar.library.pdx.edu/ open_access_etds (234).

Boers, Frank. 2000. Metaphor awareness and vocabulary retention. Applied Linguistics 21(4): 553-571.

Boers, Frank. 2003. Applied linguistics perspectives on cross-cultural variation in Conceptual Metaphor. Metaphor and Symbol 18(4): 231-238.

Boers, Frank. 2004. Expanding learners' vocabulary through metaphor awareness: What expansion, what learners, what vocabulary. In Achard, Michel \& Niemeier, Susanne (ed.) Cognitive Linguistics, Second Language Acquisition and Foreign Language Teaching. Berlin/New York: De Gruyter, 211-232.

Boers, Frank. 2013. Cognitive Linguistic approaches to teaching vocabulary: Assessment and integration. Language Teaching 46(2): 208-224.

Caballero, Rosario. 2003. Metaphor and genre: the presence and role of metaphor in the building review. Applied Linguistics, 24(2): 145-167.

Caballero, Rosario. 2006. Re-Viewing Space. Figurative Language in Architects'Assessment of Built Space. Berlin/New York: Mouton De Gruyter.

Cameron, Lynn \& Deignan, Alice. 2003. Combining large and small corpora to investigate tuning devices around metaphor in spoken discourse. Metaphor and Symbol 18(3): 149-160.

Campos-Pardillos, Miguel A. 2016. Increasing Metaphor Awareness in Legal English Teaching. ESP Today 4(2): 165-183.

Castan Pinos, Jaume. 2008. Building Fortress Europe? Schengen and the cases of Ceuta and Melilla. CIBR/WP10. Belfast: CIBR Working Papers in Border Studies.

Castaño, Emilia; Verdaguer, Isabel; Laso, Natalia Judith \& Ventura, Aaron. 2014. Economy is a living organism. Metaphorical expressions in a learner corpus of English. Spanish Journal of Applied Linguistics 27(2): 323-337. 
Catalano, Theresa. 2016. Talking About Global Migration: Implications for Language Teaching. Bristol: Multilingual Matters.

Chapetón, Marcela \& Verdaguer, Isabel. 2012. Researching linguistic metaphor in native, non-native and expert writing. In MacArthur, Fiona; Oncins-Martínez, José Luis; Sánchez-García, Manuel \& Piquer-Píriz, Ana María (eds.) Metaphor in Use: Context, Culture, and Communication. Amsterdam/Philadelphia: John Benjamins Publishing Company, 149-174.

Charteris-Black, Jonathan. 2000. Metaphor and vocabulary teaching in ESP economics. English for Specific Purposes 19: 149-165.

Charteris-Black, Jonathan. 2004. Corpus Approaches to Critical Metaphor Analysis. London: Palgrave-MacMillan.

Charteris-Black, Jonathan. 2005. Politicians and Rhetoric: The Persuasive Power of Metaphor. New York: Palgrave Macmillan.

Charteris-Black, Jonathan. 2006. Britain as a container: immigration metaphors in the 2005 election campaign. Discourse \& Society 17(5): $563-$ 581.

Chavez, Manuel \& Hoewe, Jennifer. 2012. National perspectives on state turmoil. Characteristics of elite U.S. newspaper coverage of Arizona SB 1070. In Santa Ana, Otto \& González de Bustamante, Celeste (ed.) Arizona Firestorm. Global Immigration Realities, National Media, and Provincial Politics. New York: Rowman \& Littlefield Publishers, 189202.

Cisneros, David. 2008. Contaminated Communities: The Metaphor of "Immigrant as Pollutant" in Media Representations of Immigration. Rhetoric \& Public Affairs 11(4): 569-601.

Crespo-Fernández, Eliecer. 2013. The treatment of immigrants in the current Spanish and British right-wing press: A cross-linguistic study. In Martínez-Lirola, M. (ed.) Discourses on Immigration in Times of Economic Crisis: A Critical Perspective. UK: Cambridge Scholars Publishing, 86-112.

Cunningham-Parmeter, Keith. 2011. Alien Language: Immigration Metaphors and the Jurisprudence of Otherness. Fordham Law Review 79: 15451598.

Damele, Giovanni. 2016. Adventures of a metaphor: Apian imagery in the history of political thought. In Gola, Elisabetta \& Ervas, Francesca (eds.) Metaphor and Communication. Amsterdam/Philadelphia: John Benjamins Publishing Company, 173-188.

Danesi, Marcel. 1993. Metaphorical competence in second language acquisition and second language teaching. The neglected dimension. In Altais, James (ed.) Georgetown University Round Table on Language and Linguistics. Washington DC: Georgetown University Press, 489-515. 
Danesi, Marcel. 2008. Conceptual errors in second-language learning. In de Knop, Sabine \& de Rycker, Teun (ed.) Cognitive Approaches to Pedagogical Grammar. Berlin/New York: Mouton de Gruyter, 231-256.

Deignan, Alice. 2005. Metaphor and Corpus Linguistics. Amsterdam/Philadelphia: John Benjamins Publishing Company.

Deignan, Alice; Littlemore, Jeannette \& Semino, Elena. 2013. Figurative Language, Genre and Register. Cambridge: Cambridge University Press.

Dervinyte, Inga. 2009. Conceptual emigration and immigration metaphors in the language of the press: A contrastive analysis. Studies about Languages 14: 49-55.

Duncan, Martha. G. 1994. In slime and darkness: The metaphor of filth in criminal justice. Tulane Law Review 68: 725-802.

Ebbesson, Jonas. 2008. Law, Power and Language: Beware of Metaphors. Scandinavian Studies in Law 53: 259-269.

El Refaie, Elisabeth. 2001. Metaphors we discriminate by: Naturalised themes in Austrian newspaper artices about asylum seekers. Journal of Sociolinguistics 5(3): 352-371.

Entman, Robert. 1993. Framing: Toward Clarification of a Fractured Paradigm. Journal of Communication 43(4): 51-58.

Faber, Pamela \& Márquez Linares, Carlos. 2004. The role of imagery in specialized communication. In Lewandowska-Tomaszczyk, Barbara \& Kwiatkowska, Alina (ed.) Imagery in Language. Frankfurt: Peter Lang, 585-560.

Flores, Lisa. 2003. Constructing Rhetorical Borders: Peons, Illegal Aliens, and Competing Narratives of Immigration. Critical Studies in Media Communication 20(4): 362-387.

Golden, Anne. 2012. Metaphorical expressions in L2 production: The importance of text topic in corpus research. In MacArthur, Fiona; Oncins-Martínez, José Luis; Sánchez-García, Manuel \& Piquer-Píriz, Ana M. (eds.) Metaphor in Use. Amsterdam/Philadelphia, 135-148.

Granger, Sylvianne; Dagneaux, Estelle \& Meunier, Fanny. 2002. The International Corpus of Learner English. Handbook and CD-ROM. Louvainla-Neuve: Presses universitaires de Louvain.

Hanks, Patrick. 2007. Metaphoricity is gradable. In Stefanowitsch, Anatol \& Gries, Stefan Th. (ed.) Corpus-Based Approaches to Metaphor and Metonymy. Berlin/New York: Mouton de Gruyter, 17-35.

Herrmann, J. Berenicke \& Sardinha, Tony Berber (eds.). 2015. Metaphor in Specialist Discourse. Amsterdam/Philadelphia: John Benjamins Publishing Company.

Incelli, Ersilia. 2013. Shaping reality through metaphorical patterns in legislative texts on immigration: a corpus-assisted approach. In Williams, 
Chistopher \& Tessuto, Girolamo (eds.) Language in the Negotiation of Justice Contexts, Issues and Applications. Series: Law, Language and Communication. Farnham: Ashgate, 235-256.

Jackson, Vicki. C. 2006. Constitutions as "living trees"? Comparative constitutional law and interpretive metaphors. Fordham Law Review 75: 921-960.

Johnson, Mark. 2007. Mind, Metaphor, Law. Mercer Law Review, 58(3): 845868.

Knudsen, Sanne, 2015. Framings of the concept of metaphor in biological specialist communication. In Herrmann, J. Berenicke \& Sardinha, Tony Berber (eds.) Metaphor in Specialist Discourse. Amsterdam/Philadelphia: John Benjamins Publishing Company, 191-214.

Kövecses, Zoltan. 2001. A cognitive linguistic view of learning idioms in an FLT context. In Pütz, Marti; Niemeier, Susanne \& Dirven René (eds.) Applied Cognitive Linguistics II: Language Pedagogy. Berlin: Mouton de Gruyter, 87-115.

Kövecses, Zoltan. 2002. Metaphor: A Practical Introduction. New York/Oxford: Oxford University Press.

Lakoff, George \& Johnson, Mark. 1980. Metaphors We Live By. Chicago: University of Chicago Press.

Lakoff, George \& Johnson, Mark. 1999. Philosophy in the Flesh. The Embodied Mind and its Challenge to Western Thought. Nueva York: Basic Books.

Lakoff, George.1996. Moral Politics. Chicago: University of Chicago Press.

Lakoff, George. 2004. Don't Think of an Elephant: Know your Values and Frame the Debate: The Essential Guide for Progressives. White River Junction, Vt: Chelsea Green Pub. Co.

Lakoff, George. 2006. Whose Freedom? The Battle Over America's Most Important Idea. New York: Picador.

Lakoff, George. 2008. The Political Mind. New York: Viking.

Lakoff, George \& Ferguson, Sam, 2006. The Framing of Immigration. The Rockridge Institute. http://www.rockridgeinstitute.org/research/rockridge/immigration.

Lakoff, George \& Turner, Mark. 1989. More Than Cool Reason: A Field Guide to Poetic Metaphor. Chicago: University of Chicago Press.

Lakoff, George \& Wehling, Elisabeth. 2012. The Little Blue Book: The Essential Guide to Thinking and Talking Democratic. New York: Free Press.

Larsson, Stefan. 2013. Metaphors, Law and Digital Phenomena: The Swedish Pirate Bay Court Case. International Journal of Law and Information Technology. Advance Access 21(4): 354-379. 
Littlemore, Jeannette \& Low, Graham. 2006. Metaphoric competence, second language learning, and communicative language ability. Applied Linguistics 27(2): 268-294.

Littlemore, Jeannette; Krennmayr, Tina; Turner, James \& Turner, Sarah. 2014. An investigation into metaphor use at different levels of second language writing. Applied Linguistics 35(2): 117-144.

Loughlan, Patricia. 2006. Pirates, parasites, reapers, sowers, fruits, foxes ... The metaphors of intellectual property. Sydney Law Review 28: 211226.

Musolff, Andreas. 2004. Metaphor and Political Discourse. New York: Palgrave Macmillan.

Musolff, Andreas. 2011. Migration, media and "deliberate" metaphors. metaphorik.de 21: 7-19.

Musolff, Andreas. 2015. Dehumanizing metaphors in UK immigrant debates in press and online media. Journal of Language Aggression and Conflict 3(1): 41-56.

Nacey, Susan. 2013. Metaphors in Learner English. Amsterdam/Philadelphia: John Benjamins Publishing Company.

Noah, Lars. 2000. Interpreting agency enabling acts: Misplaced metaphors in administrative law. William \& Mary Law Review 41(5): 1463-1530.

O’Brien, Gerald. 2003. Indigestible Food, Conquering Hordes, and Waste Materials: Metaphors of Immigrants and the Early Immigration Restriction Debate in the United States. Metaphor and Symbol 18(1): 33-47.

Orts Llopis, María Ángeles. 2015. Legal English and Legal Spanish: The Role of Culture and Knowledge in the Creation and Interpretation of Legal Texts. ESP Today 3(1): 1-134.

Ponterotto, Diane. 2000. The cohesive role of cognitive metaphor in discourse and conversation. In Barcelona, Antonio (ed.) Metaphor and Metonymy at the Crossroads. Berlin: Mouton de Gruyter, 283-298.

Pragglejaz Group. 2007. MIP: A Method for Identifying Metaphorically Used Words in Discourse. Metaphor and Symbol 22(1): 1-39.

Rosello, Mireille. 1999. Fortress Europe and its Metaphors. Immigration and Law. Madison: European Studies Program.

Saiz de Lobado, María Ester. 2015. Análisis de la información y análisis metafórico desde una perspectiva estadístico-lingüistica (Tesis doctoral). Alcalá: Universidad de Alcalá- Departamento de Filología.

Salager-Meyer, Francoise. 1990. Metaphors in medical English prose: A comparative study with French and Spanish. English for Specific Purposes 9(2): 145-159.

Santa Ana, Otto. 1999. Like an animal I was treated: Anti-immigrant metaphor in U.S. public discourse. Discourse and Society 10(2): 191-224. 
Santa Ana, Otto. 2002. Brown Tide Rising: Metaphors of Latinos in Contemporary American Public Discourse. Texas: University of Texas Press.

Semino, Elena. 2008. Metaphor in Discourse. Cambridge: Cambridge University Press.

Steen, Gerard; Dorst, Aletta; Herrmann, Berenike; Kaal, Anna; Krennmayr, Tina \& Pasma, Trijntje. 2010. A Method for Linguistic Metaphor Identification. Amsterdam: John Benjamins Publishing Company.

Stefanowitsch, Anatol. 2007. Corpus-Based Approaches to Metaphor and Metonymy. In Stefanowitsch, Anatol \& Gries, Stefan Th. (eds.) Corpus-Based Approaches to Metaphor and Metonymy. Berlin/New York: Mouton de Gruyter, 1-16.

Strom, Megan \& Alcock, Emily. 2017. Floods, waves, and surges: the representation of Latin@ immigrant children in the United States mainstream media. Critical Discourse Studies. doi: 10.1080/17405904.2017.1284137.

Ureña Gómez-Moreno, José Manuel. 2012. Conceptual types of terminological metaphor in marine biology. In MacArthur, Fiona; Oncins-Martínez, José Luis; Sánchez-García, Manuel \& Piquer-Píriz, Ana María (eds.) Metaphor in Use. Amsterdam/Philadelphia: John Benjamins Publishing Company, 239-260.

Van Dijk, Teun A. 2000. Ideology and Discourse: A Multidisciplinary Introduction. Barcelona: Pompeu Fabra University.

Winter, Steven L. 2001. A Clearing in the Forest: Law, Life, and Mind, Chicago and London: University of Chicago Press.

Winter, Steven L. 2006. Re-embodying Law. Mercer Law Review 58: 869-892.

Wodak, Ruth. 2006. Mediation between discourse and society: Assessing cognitive approaches in CDA. Discourse Studies 8: 179-190.

Zaiotti, Ruben. 2007. Of Friends and Fences: Europe's Neighbourhood Policy and the Gated Community Syndrome. European Integration 29(2): 143-162. 


\section{Appendix}

\section{Part 1}

1. List THREE adjectives that describe the noun immigrants

1.

2.

3.

2. List THREE verbs that combine with the noun immigration

1.

2.

3.

3. Tick the expressions that best describe the function(s) of the government/ state and order them from most significant to leastsignificant:

\begin{tabular}{|l|l|l|}
\hline Tick & Order & \\
\hline & & To prevent problems \\
\hline & & To punish \\
\hline & & To tell right from wrong \\
\hline & & To empower citizens \\
\hline & & To propose reforms \\
\hline & & To be empathic \\
\hline & & To demand responsibility \\
\hline & & To impose limits \\
\hline & & To protect the country's interests \\
\hline & & To look after citizens \\
\hline
\end{tabular}

4. Tick the expressions that best describe the function(s) of laws:

\begin{tabular}{|l|l|l|}
\hline Tick & Order & \\
\hline & & To protect \\
\hline & & To set limits \\
\hline
\end{tabular}




\begin{tabular}{|l|l|l|}
\hline Tick & Order & \\
\hline & & To control people \\
\hline & & To enforce rights \\
\hline & & To guarantee freedom \\
\hline & & To favour distinctions \\
\hline & & To promote equality \\
\hline & & To enjoy public support \\
\hline & & To reinforce diversity \\
\hline
\end{tabular}

\section{Part 2}

1. Use the following response scale to rate how well the statement below describe immigration

This does not describe immigration adequately 12345 This describes immigration perfectly

\begin{tabular}{|c|c|c|c|c|}
\hline 1 & 2 & 3 & 4 & 5 \\
very poorly & poorly & moderately well & well & perfectly well \\
\hline
\end{tabular}

\begin{tabular}{|l|lllll|}
\hline $\begin{array}{l}\text { 1. The Freedom of Movement is a great possibility to } \\
\text { connect people, learn from each other and of course it } \\
\text { makes travelling so much easier. }\end{array}$ & 1 & 2 & 3 & 4 & 5 \\
\hline $\begin{array}{l}\text { 2. France is also arming itself in preparation for a } \\
\text { wave of refugees. }\end{array}$ & 1 & 2 & 3 & 4 & 5 \\
\hline $\begin{array}{l}\text { 1. Countries have turned to immigrants to contribute } \\
\text { to economic growth. }\end{array}$ & 1 & 2 & 3 & 4 & 5 \\
\hline $\begin{array}{l}\text { 2. Britain is facing a nightly tidal wave of asylum } \\
\text { seekers from Cherbourg, France's second biggest } \\
\text { port. }\end{array}$ & 1 & 2 & 3 & 4 & 5 \\
\hline $\begin{array}{l}\text { 3. We are at a point in this nation's history where we } \\
\text { cannot afford to keep our borders porous in order to } \\
\text { provide employers with cheap labor. }\end{array}$ & 1 & 2 & 3 & 4 & 5 \\
\hline $\begin{array}{l}\text { 4. State members of the European Union have agreed } \\
\text { to develop a common immigration policy in order to } \\
\text { ensure an efficient management of migration. }\end{array}$ & 1 & 2 & 3 & 4 & 5 \\
\hline
\end{tabular}




\begin{tabular}{|l|lllll|}
\hline $\begin{array}{l}\text { 5. This global approach to migration aims to } \\
\text { encourage mobility, to ensure coherent policy making. }\end{array}$ & 1 & 2 & 3 & 4 & 5 \\
\hline $\begin{array}{l}\text { 6. The same authority that protects the borders can } \\
\text { decide on who is crossing them seeking for protection. }\end{array}$ & 1 & 2 & 3 & 4 & 5 \\
\hline $\begin{array}{l}\text { 7. America is not the only country wrestling with } \\
\text { immigration. }\end{array}$ & 1 & 2 & 3 & 4 & 5 \\
\hline $\begin{array}{l}\text { 8. There are almost no measures today to cope with } \\
\text { the problem of people's outflow. }\end{array}$ & 1 & 2 & 3 & 4 & 5 \\
\hline
\end{tabular}

\section{Part 3}

Metaphors are conceived as mechanisms used to understand one concept in terms of another - i.e., in expressions such as Lead someone step by step through an argument, follow an argument or get lost THINKING IS MOVING). They are an inextricable part of our everyday language and, despite the preconceived idea that legal language is largely free from metaphors, the use of metaphorical expressions is also pervasive in legal discourse. This fact is particularly relevant because metaphors evoke particular worldviews and highlight certain aspects of a phenomenon while downplaying other parts.

Thus, for example, when terms such as flows, influx or curbs are used to describe immigration laws, IMMIGRATION is conceived of as a FLOOD, which brings about negative connotations and dehumanizes immigrants. Likewise, when national borders as defined as areas whose security must be protected against immigration, immigrants are seen as a source of security problems and a threat to the stability of the country. Metaphors are more than figures of speech, the choice of a metaphor over other can profoundly affect the manner in which legal thought is affected (Berger, 2002; Cunningham-Parmeter, 2011; Santa Ana, 1997)

1. Were you aware that legal language was highly metaphorical?

\begin{tabular}{|l|l|}
\hline YES & \\
\hline NO & \\
\hline
\end{tabular}

2. Had you ever realized that the use of terms such as those mentioned above evoke negative connotations? Explain briefly. 